\title{
Birth traits of pure Holstein calves versus Montbeliarde-sired crossbred calves
}

\author{
B. J. Heins, ${ }^{1}$ L. B. Hansen, A. R. Hazel, A. J. Seykora, D. G. Johnson, and J. G. Linn \\ Department of Animal Science, University of Minnesota, St. Paul 55108
}

\section{ABSTRACT}

Pure Holstein calves and Montbeliarde-sired crossbred calves from multiparous Holstein dams were compared for gestation length, calf weight at birth, calving difficulty, and stillbirth in 2 research herds of the University of Minnesota. The Montbeliarde-sired calves from multiparous Holstein dams had significantly longer gestation lengths $(283.2 \mathrm{~d})$ than Holstein-sired calves from Holstein dams $(278.4 \mathrm{~d})$, and Montbeliarde-sired calves from multiparous Holstein dams had significantly greater calf weight at birth $(48.3 \mathrm{~kg})$ compared with Holstein-sired calves from Holstein dams (43.3 $\mathrm{kg}$ ). However, calves sired by Montbeliarde bulls were not significantly different from calves sired by Holstein bulls for calving difficulty and stillbirth. In addition, Jersey $\times$ Holstein crossbred cows mated to Montbeliarde artificial insemination (AI) bulls were compared with pure Holstein cows mated to Holstein AI bulls for gestation length, calf weight at birth, calving difficulty, and stillbirth at their first 3 calvings. Gestation length was significantly longer for Jersey $\times$ Holstein cows bred to Montbeliarde bulls than for pure Holstein cows bred to Holstein bulls at first calving (280.3 versus $277.7 \mathrm{~d}$ ) and second and third calving (282.2 versus $278.6 \mathrm{~d}$ ); however, Jeresy $\times$ Holstein cows bred to Montbeliarde AI bulls were not significantly different from pure Holstein cows bred to Holstein AI bulls for calf weight at birth, calving difficulty, and stillbirth at the first 3 calvings.

Key words: crossbreeding, gestation length, calving difficulty, stillbirth

\section{INTRODUCTION}

Dairy producers around the world have turned to mating pure Holstein (HO) heifers and cows to AI bulls from breeds of dairy cattle other than $\mathrm{HO}$, especially Jersey $(\mathbf{J E})$ and the Scandinavian Red breeds, to reduce calving difficulty (CD) of cows and stillbirth (SB) of

Received November 13, 2009.

Accepted January 29, 2010.

${ }^{1}$ Corresponding author: hein0106@umn.edu calves. In a survey conducted by Weigel and Barlass (2003), dairy producers indicated pure HO cows had less $\mathrm{CD}$ and SB when bred to AI bulls that were nonHO compared with HO. Loss of production, reduced fertility, increased health problems, and decreased survival of cows are some of the consequences of increased CD and SB (Zaborski et al., 2008). Furthermore, HO cows that deliver SB calves have reduced fertility and a greater risk of being culled (Bicalho et al., 2007).

Meyer et al. (2001) reported 29\% of first-calf $\mathrm{HO}$ heifers and $11 \%$ of multiparous $\mathrm{HO}$ cows had CD, and Lombard et al. (2007) reported 19\% of first-calf HO heifers and $7 \%$ of multiparous $\mathrm{HO}$ cows had $\mathrm{CD}$ when bred to HO bulls. The SB rate in Minnesota DHI herds was reported to be $11.3 \%$ by Silva del Río et al. (2007), and SB rates have increased 3.7 percentage units from 1985 to 1996 in the United States for HO (Meyer et al., 2001). Those HO cows with CD are more likely to deliver calves with $\mathrm{SB}$, digestive problems, and greater mortality after birth (Mee, 2008).

Many studies have reported less CD and fewer SB when mating $\mathrm{HO}$ heifers and cows with bulls from other breeds (Hollon and Branton, 1975; Vesely et al., 1986; Touchberry, 1992; Olson et al., 2009). Vesely et al. (1986) reported pure HO calves (15.1\%) had a greater SB rate than did Ayrshire-sired calves (10.7\%) from HO dams at first calving, and pure HO cows (14.5\%) had significantly more SB than Ayrshire $\times$ HO crossbred cows (6.4\%) at first calving. Touchberry (1992) found Guernsey and HO crossbred calves had fewer SB $(6.2 \%)$ than the mean of pure Guernsey and pure HO calves $(9.0 \%)$. In addition, JE $\times$ HO calves had significantly less CD than, but similar SB to, pure HO calves, as reported by Olson et al. (2009).

Heins et al. (2006) reported CD and SB from a crossbreeding study of 7 large commercial dairies in California, and calves sired by Montbeliarde (MO) AI bulls were not significantly different for CD (11.6\% for $\mathrm{MO}$ versus $16.4 \%$ for $\mathrm{HO}$ ) or $\mathrm{SB}$ ( $12.7 \%$ for $\mathrm{MO}$ versus $15.1 \%$ for $\mathrm{HO}$ ) from pure $\mathrm{HO}$ calves from pure $\mathrm{HO}$ dams at first calving. For multiparous pure $\mathrm{HO}$ dams in the same study, Brown Swiss- $(4.9 \%)$, Normande- $(8.7 \%)$, and MO-sired $(5.4 \%)$ calves were not significantly different from HO-sired $(8.4 \%)$ calves for 
CD; however, Brown Swiss- (5.6\%), Normande- (7.3\%), and MO-sired (5.0\%) calves had significantly lower SB rates than $\mathrm{HO}$-sired $(12.7 \%)$ calves from multiparous pure $\mathrm{HO}$ cows.

Few studies have documented the effects of crossbreeding on gestation length $(\mathbf{G L})$ and calf weight at birth (CW). Touchberry and Bereskin (1966) reported Guernsey-sired calves from pure HO dams had 5-d longer GL, but $1.7-\mathrm{kg}$ less $\mathrm{CW}$, than pure $\mathrm{HO}$ calves. In the same study, calves from crossbred cows had 1.2-d less GL, but greater CW, than the mean of the 2 pure breeds. Christensen et al. (1984) found pure HO calves had 2.3-d longer GL than crossbred calves of HO and Red Dane. For crossbreds of Ayrshire, Brown Swiss, and $\mathrm{HO}$, McDowell (1982) reported no difference in CW of Ayrshire $\times \mathrm{HO}$ calves and Brown Swiss $\times \mathrm{HO}$ calves compared with pure $\mathrm{HO}$ calves. Although greater CW is associated with more $\mathrm{CD}$ and an increased $\mathrm{SB}$ rate (Johanson and Berger, 2003) within the HO breed, it is unclear if that association applies to crossbred calves.

The MO breed is based in the Franche-Comte region of France and was introduced to North America and other countries globally over the past decade. At this time, the breed has more than 410,000 recorded cows, and at least 120 young bulls are progeny tested annually in France. Unlike in many dairy breeds, in the MO breed, there has been selection for greater body condition instead of for more angularity. The Brown Swiss, Fleckvieh, and MO breeds of dairy cattle originate from the Alps region of Europe, and these 3 breeds share longer GL compared with the dairy breeds of northern Europe and North America. Because GL is a trait of the calf, MO-sired crossbred calves are expected to have lengthened GL compared with pure HO calves.

The objectives of this study were to investigate the GL, CW, CD, and SB of calves and their dams in 2 research herds of the University of Minnesota. Two groups of cows were compared in both herds: 1) pure $\mathrm{HO}$ cows at second and later calving mated to $\mathrm{HO} \mathrm{AI}$ bulls versus MO AI bulls and 2) pure HO cows at first, second, and third calving mated to HO AI bulls versus $\mathrm{JE} \times \mathrm{HO}$ crossbred cows at first, second, and third calving mated to MO AI bulls. The GL of dairy cattle has seldom been studied, and CW is not routinely recorded by dairy producers. On the other hand, large data files are collected in the field and used to assess $\mathrm{CD}$ and $\mathrm{SB}$ within the $\mathrm{HO}$ breed; however, data on $\mathrm{CD}$ and SB of MO-sired crossbred calves are not systematically recorded in the field at this time. Therefore, data from institutional research herds, although limited in scope, are valuable to assess traits such as CD and SB for MO-sired crossbred calves.

\section{MATERIALS AND METHODS}

\section{Experimental Design}

The research dairy on the St. Paul campus of the University of Minnesota has 90 tie stalls and a compost barn that accommodates 40 animals, and the West Central Research and Outreach Center, Morris, Minnesota, has a low-input grazing system that accommodates 150 animals. The 2 research herds have shared a crossbreeding design since 2000. To initiate research on crossbreeding, pure $\mathrm{HO}$ heifers and cows were randomly assigned to either the pure $\mathrm{HO}$ or crossbred lines in both herds. The HO heifers and cows in the pure HO line were bred to HO AI bulls, and the HO heifers and cows in the crossbred line were bred to JE AI bulls. All of the resulting $\mathrm{JE} \times \mathrm{HO}$ crossbred heifers, which were born from 2001 to 2003, were mated to MO AI bulls during their lifetimes to initiate a 3-breed rotational system for crossbreeding.

Subsequently, beginning in 2002, some multiparous pure $\mathrm{HO}$ cows in both research herds were mated to MO AI bulls to provide for the comparison of pure $\mathrm{HO}$ and $\mathrm{MO} \times \mathrm{HO}$ crossbreds. Pure $\mathrm{HO}$ cows were randomly mated to either MO AI bulls or HO AI bulls; however, no pure $\mathrm{HO}$ virgin heifers were mated to $\mathrm{MO}$ bulls because of the crossbreeding design in the 2 research herds.

For all breeds (HO, JE, and MO), 3 AI bulls were selected annually based on ranking with the Net Merit index for HO and JE (VanRaden et al., 2006) and with the French ISU total merit index for MO (Coopex Montbeliarde, 2009). The cattle in the pure HO line at Morris that had difficulty in conception were mated to progeny-test HO AI bulls to save cost. In addition, one set of $3 \mathrm{MO}$ AI bulls had repeated use for a second year. Crossbreds may benefit from heterosis for some traits, and purebreds may be negatively affected by inbreeding depression; therefore, inbreeding coefficients were not allowed to surpass $6.25 \%$ for mating of $\mathrm{HO}$ bulls with $\mathrm{HO}$ females.

\section{Recording of Data}

The GL, CW, CD, and SB were recorded for calvings from August 2003 to January 2009 at both St. Paul and Morris. The GL was the date of conception subtracted from the date of calving, and CW was recorded within $48 \mathrm{~h}$ of birth. Body weight of dams at calving was not recorded. The CD was measured on a 5-point scale, with 1 = quick, easy birth with no assistance; $2=$ over $2 \mathrm{~h}$ in labor, but no assistance; $3=$ minimum assistance, but no calving difficulty; $4=$ used obstetrical 
Table 1. Number of observations, least squares means, standard errors of means, and significance from the logistical regression statistical test for gestation length, calf weight, calving difficulty, and stillbirth of calves from multiparous Holstein cows bred to Holstein versus Montbeliarde AI bulls ${ }^{1}$

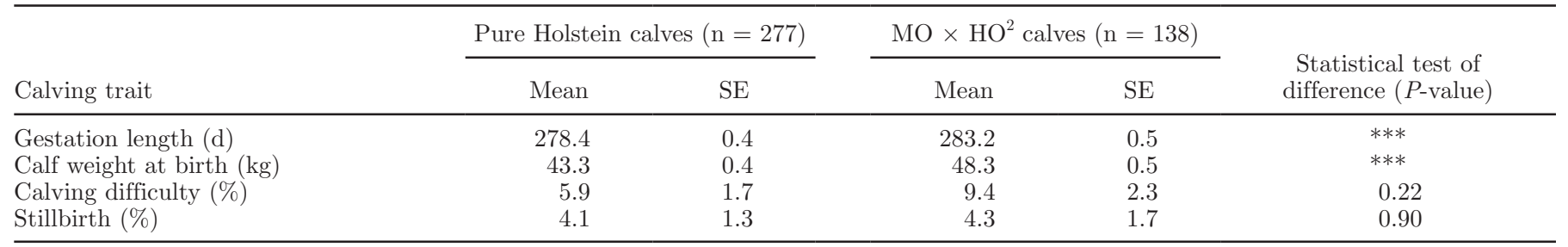

${ }^{1}$ Independent variables for statistical analysis were sex of calf, herd, and breed of sire.

${ }^{2}$ Montbeliarde $\times$ Holstein.

$* * * P<0.001$.

chains; and $5=$ extremely difficult birth that required a mechanical puller. For analysis, scores of 1 to 3 were combined and represented no CD, whereas scores of 4 and 5 were combined and represented $\mathrm{CD}$. The SB was recorded in a binary manner as living (1) or dead (0) within $24 \mathrm{~h}$ of birth.

In total, 415 calvings (Table 1 ) were analyzed for the comparison of GL, CD, and SB for multiparous pure HO cows bred to either HO AI bulls (277 calves sired by 32 bulls) or MO AI bulls (138 calves sired by 12 bulls), after the removal of 27 twin calvings ( 20 for pure $\mathrm{HO}, 7$ for $\mathrm{MO} \times \mathrm{HO})$. The pure $\mathrm{HO}$ cows calved for the second $(\mathrm{n}=148)$, third $(\mathrm{n}=117)$, fourth $(\mathrm{n}=78)$, or fifth and greater $(\mathrm{n}=72)$ time. The $\mathrm{CW}$ observations were missing for 11 pure $\mathrm{HO}$ calves and $4 \mathrm{MO} \times \mathrm{HO}$ calves; therefore, 400 multiparous calvings of pure HO cows (266 bred to HO, 134 bred to MO) were analyzed for CW (Table 2).

Data for calvings of 77 pure $\mathrm{HO}$ heifers bred to $\mathrm{HO}$ $\mathrm{AI}$ bulls versus $78 \mathrm{JE} \times \mathrm{HO}$ heifers bred to $\mathrm{MO} \mathrm{AI}$ bulls were available for comparison at first calving (Table 3). After the removal of data for 8 sets of twins at first calving ( 3 for $\mathrm{HO}$ and 5 for $\mathrm{JE} \times \mathrm{HO}$ ), 74 pure HO first-calf heifers (calves sired by 8 bulls) and $73 \mathrm{JE} \times \mathrm{HO}$ first-calf heifers (calves sired by 6 bulls) were compared for GL, CD, and SB. The CW was not recorded for 2 calves at Morris; therefore, 74 pure $\mathrm{HO}$ versus $71 \mathrm{JE} \times \mathrm{HO}$ were compared (Table 4 ).
For second and third calving, 86 pure $\mathrm{HO}$ cows bred to HO AI bulls (calves sired by 15 bulls) and $104 \mathrm{JE} \times$ HO cows bred to MO AI bulls (calves sired by 11 bulls) were analyzed (Table 3 ). Eleven twin calvings (2 for pure $\mathrm{HO}$ dams and 9 for $\mathrm{JE} \times \mathrm{HO}$ dams) and 3 lateterm abortions ( 1 for pure $\mathrm{HO}, 2$ for $\mathrm{JE} \times \mathrm{HO}$ dams) were removed from the data. Two pure $\mathrm{HO}$ calves and one crossbred calf were not recorded for $\mathrm{CW}$, so 84 pure HO calves and 103 crossbred calves were compared (Table 4).

Both the St. Paul and Morris herds breed seasonally, and all virgin heifers for both locations were reared and mated at Morris. The St. Paul herd calved mostly in the fall, and the Morris herd calved mostly in the spring. Season of calving was spring (March to July) or fall (September to February). Seasons with fewer than 10 calvings and seasons containing less than 5 calvings for each genetic group were combined (fall season with following spring season) at Morris.

\section{Statistical Analyses}

Dependent variables in models for statistical analyses in all cases were GL, CW, CD, and SB. For comparison of multiparous pure $\mathrm{HO}$ cows bred to $\mathrm{HO}$ AI bulls versus MO AI bulls, independent variables were the fixed effects of sex of calf, herd, and breed of sire, along with cow as a random effect. A preliminary model included

Table 2. Number of calvings and stratification of calf weights of Holstein-sired calves and Montbeliarde-sired calves from multiparous pure Holstein dams ${ }^{1}$

\begin{tabular}{|c|c|c|c|c|}
\hline \multirow[b]{2}{*}{ Item } & \multicolumn{2}{|c|}{ Pure Holstein calves } & \multicolumn{2}{|c|}{$\mathrm{MO} \times \mathrm{HO}^{2}$ calves } \\
\hline & $\mathrm{n}$ & $\%$ & $\mathrm{n}$ & $\%$ \\
\hline \multicolumn{5}{|c|}{ Calf weight at birth } \\
\hline$\leq 50 \mathrm{~kg}$ & 243 & 91 & 91 & 68 \\
\hline$\overline{51}-60 \mathrm{~kg}$ & 23 & 9 & 36 & 27 \\
\hline$>60 \mathrm{~kg}$ & 0 & 0 & 7 & 5 \\
\hline Total & 266 & 100 & 134 & 100 \\
\hline
\end{tabular}


Table 3. Number of observations, least squares means, standard errors of means, and significance from the logistical regression statistical test for gestation length, calf weight, calving difficulty, and stillbirth of Holstein cows bred to Holstein AI bulls and Jersey $\times$ Holstein crossbred cows bred to Montbeliarde AI bulls for first calving and second and third calving ${ }^{1}$

\begin{tabular}{|c|c|c|c|c|c|c|c|c|c|c|}
\hline \multirow[b]{3}{*}{ Calving trait } & \multicolumn{5}{|c|}{ First calving } & \multicolumn{5}{|c|}{ Second and third calving } \\
\hline & \multicolumn{2}{|c|}{$\begin{array}{c}\text { Pure Holstein } \\
\text { calves }(\mathrm{n}=74)\end{array}$} & \multicolumn{2}{|c|}{$\begin{array}{c}\mathrm{MO} \times(\mathrm{JE} \times \\
\mathrm{HO})^{2}(\mathrm{n}=73)\end{array}$} & \multirow{2}{*}{$\begin{array}{c}P \text {-value } \\
\text { from test of } \\
\text { difference }\end{array}$} & \multicolumn{2}{|c|}{$\begin{array}{c}\text { Pure Holstein } \\
\text { calves }(\mathrm{n}=86)\end{array}$} & \multicolumn{2}{|c|}{$\begin{array}{c}\mathrm{MO} \times(\mathrm{JE} \times \\
\mathrm{HO})^{2}(\mathrm{n}=104) \\
\end{array}$} & \multirow{2}{*}{$\begin{array}{c}P \text {-value } \\
\text { from test o } \\
\text { difference }\end{array}$} \\
\hline & Mean & $\mathrm{SE}$ & Mean & $\mathrm{SE}$ & & Mean & $\mathrm{SE}$ & Mean & $\mathrm{SE}$ & \\
\hline Gestation length (d) & 277.7 & 0.8 & 280.3 & 0.7 & $* *$ & 278.6 & 0.6 & 282.2 & 0.6 & $* * *$ \\
\hline Calf weight at birth $(\mathrm{kg})$ & 38.9 & 0.6 & 37.6 & 0.6 & $\dagger$ & 42.5 & 0.6 & 41.9 & 0.6 & 0.47 \\
\hline
\end{tabular}

${ }^{1}$ Independent variables for statistical analysis were sex of calf, herd, season nested within herd, and genetic group. For second and third calving, parity nested within genetic group was also included.

${ }^{2}$ Montbeliarde-sired calves from Jersey $\times$ Holstein crossbred dams.

$\dagger P<0.10 ;{ }^{* *} P<0.01 ; * * P<0.001$.

the effects of parity, season of calving nested within herd, interaction of sex of calf and breed of sire, and interaction of herd and breed of sire. However, none of these fixed effects significantly $(P>0.30)$ explained variation of any dependent variable; therefore, they were removed from the models. The MIXED procedure of SAS (SAS Institute, 2004) was used to obtain solutions; however, the GLIMMIX procedure of SAS was used to determine the statistical significance for CD and SB because both are binary traits. For CW, a $\chi^{2}$ test (SAS Institute, 2004) was conducted for breed of sire and stratification of $\mathrm{CW}$.

For the first-calf comparison of pure $\mathrm{HO}$ bred to $\mathrm{HO}$ AI bulls and JE $\times$ HO bred to MO AI bulls, independent variables were sex of calf, herd, season of calving nested within herd, and genetic group. To analyze second and third calving, independent variables were sex of calf, herd, season of calving nested within herd, genetic group, and parity nested within genetic group as fixed effects, and cow nested within genetic group as a random effect. Preliminary models included the effects of interaction of sex of calf and breed of sire and interaction of herd and genetic group; however, interaction effects were not significant $(P>0.20)$ for any of the dependent variables and were removed from the model. The GLM procedure of SAS (SAS Institute, 2004) was used to obtain solutions for first calving, and the MIXED procedure of SAS (SAS Institute, 2004) was used to obtain solutions for second and third calving. However, the LOGISTIC procedure of SAS was used for first calving and the GLIMMIX procedure of SAS was used for second and third calving to assess the statistical significance of variables influencing CD and SB. For CW, a $\chi^{2}$ test (SAS Institute, 2004) was conducted for genetic group and stratification of CW.

\section{RESULTS AND DISCUSSION}

\section{Calvings of Multiparous Pure HO Cows Bred to HO Bulls Versus MO Bulls}

Bull calves had significantly $(P<0.05)$ longer GL $(1.2 \mathrm{~d})$ than heifer calves and significantly $(P<0.01)$ greater $\mathrm{CW}$ than heifer calves $(4.1 \mathrm{~kg})$ for pure $\mathrm{HO}$ cows bred to either HO bulls or MO bulls. Norman et al. (2009) reported bull calves had longer GL than

Table 4. Number of calvings and stratification of calf weights of Holstein-sired calves from Holstein dams and Montbeliarde-sired calves from Jersey $\times$ Holstein dams for first calving versus second and third calving ${ }^{1}$

\begin{tabular}{|c|c|c|c|c|}
\hline \multirow[b]{2}{*}{ Item } & \multicolumn{2}{|c|}{ First calving } & \multicolumn{2}{|c|}{ Second and third calving } \\
\hline & $\begin{array}{l}\text { Pure Holstein } \\
\text { calves }\end{array}$ & $\begin{array}{c}\mathrm{MO} \times \\
(\mathrm{JE} \times \mathrm{HO})^{2}\end{array}$ & $\begin{array}{l}\text { Pure Holstein } \\
\text { calves }\end{array}$ & $\begin{array}{c}\mathrm{MO} \times \\
(\mathrm{JE} \times \mathrm{HO})^{2}\end{array}$ \\
\hline \multicolumn{5}{|c|}{ Calf weight at birth } \\
\hline$\leq 50 \mathrm{~kg}$ & 74 & 71 & 81 & 97 \\
\hline$\overline{51}-60 \mathrm{~kg}$ & 0 & 0 & 3 & 6 \\
\hline$>60 \mathrm{~kg}$ & 0 & 0 & 0 & 0 \\
\hline Total & 74 & 71 & 84 & 103 \\
\hline
\end{tabular}

${ }^{1}$ Chi-squared test for stratification of calf weight at birth versus genetic group was not significant $(P=0.47)$.

${ }^{2}$ Montbeliarde-sired calves from Jersey $\times$ Holstein crossbred dams. 
heifer calves within breed, and Kertz et al. (1997) and Maltecca et al. (2006) found CW of bull calves is greater than $\mathrm{CW}$ of heifer calves within the $\mathrm{HO}$ breed. Furthermore, sex of calf explained a significant $(P<$ 0.05 ) difference for CD (11.9\% for bull calves and $4.3 \%$ for heifer calves) of the multiparous $\mathrm{HO}$ cows, but $\mathrm{SB}$ (3.6\% for bull calves and $4.8 \%$ for heifer calves) was not significantly $(P=0.57)$ different for sex of calf.

The CW was significantly $(P<0.01)$ greater $(1.9 \mathrm{~kg})$ for calves born at St. Paul than for calves born at Morris. In addition, $\mathrm{CD}$ was significantly $(P<0.01)$ greater at St. Paul (12.4\%) than at Morris $(2.9 \%)$, which could be due to the difference in housing (stall barn versus pasture) or to a higher rate of unobserved calvings at Morris than at St. Paul.

Table 1 has the number of observations, least squares means, and standard errors of means for GL, CW, CD, and SB from multiparous $\mathrm{HO}$ dams for $\mathrm{HO}$-sired calves compared with MO-sired calves. The pure HO calves had significantly $(P<0.001)$ shorter GL $(4.8 \mathrm{~d})$ than $\mathrm{MO} \times \mathrm{HO}$ calves from multiparous $\mathrm{HO}$ dams. The GL of pure $\mathrm{HO}$ calves in this study is similar to the GL of 279 d reported by Norman et al. (2009), and Dillon et al. (2003) found pure MO calves had 4-d longer GL than pure $\mathrm{HO}$ calves across all calvings. The GL is primarily determined by breed composition of the calf, and the 4.8-d difference in GL found in this study could result in a difference in CW (Jamrozik et al., 2005). Indeed, pure HO calves had significantly $(P<0.001)$ less $\mathrm{CW}(5.0 \mathrm{~kg})$ than $\mathrm{MO} \times \mathrm{HO}$ calves from multiparous pure HO dams.

Although the $\mathrm{MO} \times \mathrm{HO}$ calves had greater mean $\mathrm{CW}$ than the pure $\mathrm{HO}$ calves from multiparous $\mathrm{HO}$ dams, the $\mathrm{MO} \times \mathrm{HO}$ calves were not significantly different from the pure $\mathrm{HO}$ calves for $\mathrm{CD}$. The least squares means for $\mathrm{CD}$ in this study were $5.9 \%$ for pure $\mathrm{HO}$ calves versus $9.4 \%$ for $\mathrm{MO} \times \mathrm{HO}$ crossbred calves and reflected CD for 18 of 277 pure $\mathrm{HO}$ calves and 13 of $138 \mathrm{MO} \times \mathrm{HO}$ calves. However, this nonsignificant $(P=0.22)$ difference in percentage units for $\mathrm{CD}$ is in the opposite direction from the nonsignificant $(P=$ 0.29) difference for CD in Heins et al. (2006) for calves from multiparous pure $\mathrm{HO}$ dams. For that study, $8.4 \%$ for pure $\mathrm{HO}$ calves and $5.4 \%$ for $\mathrm{MO} \times \mathrm{HO}$ crossbred calves had CD, with more observations (303 pure HO calves and 2,373 $\mathrm{MO} \times \mathrm{HO}$ calves) than in the present study. Furthermore, first-calving $\mathrm{HO}$ dams in Heins et al. (2006) had 16.4\% CD for pure HO calves compared with $11.6 \% \mathrm{CD}$ for $\mathrm{MO} \times \mathrm{HO}$ calves. The $5.9 \%$ rate of $\mathrm{CD}$ for pure $\mathrm{HO}$ calves from multiparous $\mathrm{HO}$ dams in this study is somewhat less than the $8.4 \%$ of Heins et al. (2006) and the $6.9 \%$ of Lombard et al. (2007).

For SB, pure $\mathrm{HO}$ calves in this study did not differ significantly $(P=0.90)$ from $\mathrm{MO} \times \mathrm{HO}$ calves $(4.1$ ver- sus $4.3 \%$, respectively). On the other hand, the 2,373 $\mathrm{MO} \times \mathrm{HO}$ calves from multiparous $\mathrm{HO}$ dams in Heins et al. (2006) had significantly $(P<0.01)$ fewer SB than the 303 pure HO calves (5.0 versus $12.7 \%$, respectively). In addition, the SB rate of pure $\mathrm{HO}$ calves in this study (4.1\%) is less than the $5.7 \%$ SB of Meyer et al. (2000) and the $14.2 \% \mathrm{SB}$ of Maltecca et al. (2006) but greater than the 2.9\% SB of Hossein-Zadeh et al. (2008).

The weighted means of genetic evaluations of the HO sires of calves in this study were $6.8 \%$ for direct CD (percentage of difficult births in heifers) and $7.6 \%$ for direct SB (January 2009 genetic evaluation of USDAAIPL), which are both lower than the mean evaluations $(\mathrm{CD}=7.5 \%$ and $\mathrm{SB}=7.9 \%)$ for these traits for the HO breed in the United States (Cole, 2005; Cole, 2006). The MO sires in this study had a weighted mean of genetic evaluation for CD (percentage of births in heifers without any form of assistance) of 90.6 in France (February 2009 genetic evaluations from INRA), which is superior to the 88.7 mean for the MO breed. Evaluations for SB are not published for MO bulls in France; however, the mean for the MO breed is $4.6 \%$ in France. Therefore, the HO and MO AI bulls selected for this study tended to be among the better bulls for CD and SB within both breeds.

Table 2 has the number of calvings and stratification of $\mathrm{CW}$ for pure $\mathrm{HO}$ calves versus $\mathrm{MO} \times \mathrm{HO}$ calves from multiparous pure $\mathrm{HO}$ dams. Calves $\leq 50 \mathrm{~kg}$ for $\mathrm{CW}$ should be born without $\mathrm{CD}$, and most calves from 51 to $60 \mathrm{~kg}$ would not be expected to have CD when born to multiparous pure $\mathrm{HO}$ dams. However, calves $>60 \mathrm{~kg}$ would be regarded as quite large for multiparous pure $\mathrm{HO}$ cows by most dairy producers, and 7 of the $134 \mathrm{MO}$ $\times \mathrm{HO}$ calves (or $5 \%$ of the 134 calves) compared with zero pure $\mathrm{HO}$ calves were $>60 \mathrm{~kg}$. The $7 \mathrm{MO}$-sired calves $>60 \mathrm{~kg}$ ( 6 bull calves and 1 heifer calf) had a mean $\mathrm{CW}$ of $63.0 \mathrm{~kg}$; however, only 3 of the 7 calves were born with $\mathrm{CD}$. The $7 \mathrm{MO} \times \mathrm{HO}$ calves $>60 \mathrm{~kg}$ in this study could lead to concern among dairy producers regarding use of MO in a crossbreeding system. However, these large $\mathrm{MO} \times \mathrm{HO}$ calves did not result in a significantly $(P=0.22)$ greater mean $\mathrm{CD}$ or a significantly $(P=$ $0.90)$ increased mean SB rate compared with pure HO calves. Nogalski (2003) reported body shape of calves may influence CD and SB, which could explain the lack of significant differences for $\mathrm{CD}$ of the pure $\mathrm{HO}$ calves versus $\mathrm{MO} \times \mathrm{HO}$ calves in this study and in Heins et al. (2006).

\section{Calvings of Pure HO Cows Versus JE $\times$ HO Crossbred Cows}

The GL was significantly $(P<0.05)$ longer $(2.0 \mathrm{~d})$ for bull calves than heifer calves at first calving, and CW 
was significantly greater $(P<0.01)$ for bull calves than heifer calves at both first calving $(2.7 \mathrm{~kg})$ and second and third calving $(3.7 \mathrm{~kg})$ for the pure $\mathrm{HO}$ cows and JE $\times$ HO cows. However, sex of calf did not significantly $(P>0.30)$ affect $\mathrm{CD}$ or SB.

Table 3 has numbers of observations, least squares means, and standard errors of means for $\mathrm{HO}$ cows bred to $\mathrm{HO}$ bulls and $\mathrm{JE} \times \mathrm{HO}$ cows bred to MO bulls for first-calf heifers versus cows calving for the second and third times. The GL was significantly $(P<0.01)$ longer for MO-sired calves from $\mathrm{JE} \times \mathrm{HO}$ dams than for pure HO calves at first calving $(2.6 \mathrm{~d})$ and at second and third calving $(3.6 \mathrm{~d})$. However, $\mathrm{CW}$ tended $(P<0.10)$ to be less $(1.3 \mathrm{~kg})$ at first calving, and $\mathrm{CW}$ was not different $(P=0.47)$ at second and third calving for MO-sired calves from $\mathrm{JE} \times \mathrm{HO}$ dams than for pure HO calves.

Number of calvings and stratification of $\mathrm{CW}$ of pure $\mathrm{HO}$ calves versus MO-sired calves from $\mathrm{JE} \times \mathrm{HO}$ dams are shown in Table 4. At first calving, $\mathrm{CW}$ was $\leq 50$ $\mathrm{kg}$ for all calves, both pure $\mathrm{HO}$ calves and crossbred calves. Similarly, at second and third calving, $\mathrm{CW}$ was no more than $60 \mathrm{~kg}$ for any calf. Therefore, JE $\times \mathrm{HO}$ virgin heifers and cows may be mated to MO AI bulls without concern about their calves having greater $\mathrm{CW}$ than pure HO calves. Although MO-sired calves from JE $\times$ HO dams had longer GL than pure HO calves, the $50 \%$ JE content of the dams and the $25 \%$ JE content of the calves apparently counteract the $50 \% \mathrm{MO}$ content of the calves; therefore, the consequences of mating cows to MO AI bulls differ in Tables 2 (MO from pure $\mathrm{HO}$ dams) and 4 ( $\mathrm{MO}$ from $\mathrm{JE} \times \mathrm{HO}$ dams $)$ for CW.

Least squares means for $\mathrm{CD}$ of pure $\mathrm{HO}$ calves versus MO-sired calves from $\mathrm{JE} \times \mathrm{HO}$ dams had no tendency to differ at first calving $(P=0.36)$ or at second and third calving $(P=0.44)$. At first calving, 10 of 74 pure HO calves compared with 14 of 73 MO-sired calves from $\mathrm{JE} \times \mathrm{HO}$ dams had $\mathrm{CD}$. At second and third calving, 3 of 86 pure HO compared with 5 of 104 MOsired calves from JE $\times$ HO dams had CD. Likewise, the least squares means for SB did not differ $(P \geq 0.50)$ for genetic groups at first calving or at second and third calving.

\section{CONCLUSIONS}

The mean GL of MO-sired calves was longer than the mean GL of pure $\mathrm{HO}$ calves in this study. In addition, the mean $\mathrm{CW}$ of $\mathrm{MO} \times \mathrm{HO}$ crossbred calves was significantly greater $(5 \mathrm{~kg})$ than the $\mathrm{CW}$ of pure $\mathrm{HO}$ calves from multiparous HO dams; however, data were not available for calves from HO heifers bred to MO AI bulls in this study. The mean $\mathrm{CW}$ of MO-sired calves from $\mathrm{JE} \times \mathrm{HO}$ dams were no greater than the mean $\mathrm{CW}$ of pure $\mathrm{HO}$ calves at first calving and at second and third calving.

Variation within genetic groups (pure HO calves and MO-sired crossbred calves) for CD and SB was substantial and overwhelmed any potential differences between genetic groups both in this study and in Heins et al. (2006). Based on results from this study and previous research, MO AI bulls should not be eliminated from consideration by dairy producers for crossbreeding systems because of concerns that longer GL or greater CW of their calves will result in greater CD or increased SB rates, at least for multiparous $\mathrm{HO}$ cows and $\mathrm{JE} \times \mathrm{HO}$ crossbred heifers or cows. Nonetheless, dairy producers should consider genetic evaluations for CD of potential MO service sires, just as they are urged to do when choosing among potential HO service sires, especially for mating virgin heifers.

\section{ACKNOWLEDGMENTS}

The authors express gratitude to Bill Hansen and coworkers at St. Paul and Darin Huot and coworkers at Morris for their assistance in data collection and care of animals. Financial support was provided for this project by the American Jersey Cattle Club Research Foundation (Reynoldsburg, Ohio) and Coopex Montbéliarde (Roulans, France).

\section{REFERENCES}

Bicalho, R. C., K. N. Galvão, S. H. Cheong, R. O. Gilbert, L. D Warnick, and C. L. Guard. 2007. Effect of stillbirths on dam survival and reproduction performance in Holstein dairy cows. J. Dairy Sci. 90:2797-2803.

Christensen, L. G., R. Barlow, and A. Neimann-Sørensen. 1984. Crossbreeding Red Danish, Holstein-Friesian, and Finnish Ayrshire. Acta Agric. Scand. 34:463-479.

Cole, J. B. 2005. Brown Swiss and Holstein calving ease. http://www. aipl.arsusda.gov/reference/fertility/ce2005.htm Accessed July 25, 2009.

Cole, J. B. 2006. Genetic evaluation of stillbirth. http://aipl.arsusda. gov/reference/fertility/sb2006.html Accessed July 25, 2009.

Coopex Montbeliarde. 2009. A unique selection program. http://www. coopex.com/un-programme-de-selection-incomparable-en.php Accessed Dec. 22, 2009

Dillon, P., S. Snijders, F. Buckley, B. Harris, P. O'Connor, and J. F. Mee. 2003. A comparison of different dairy cow breeds on a seasonal grass-based system of milk production. 2. Reproduction and survival. Livest. Prod. Sci. 83:35-42.

Hossein-Zadeh, N. G., A. Nejati-Javaremi, S. R. Miraei-Ashtiani, and H. Kohram. 2008. An observational analysis of twin births, calf stillbirth, calf sex ratio, and abortion in Iranian Holsteins. J. Dairy Sci. 91:4198-4205.

Heins, B. J., L. B. Hansen, and A. J. Seykora. 2006. Calving difficulty and stillbirths of pure Holsteins versus crossbreds of Holstein with Normande, Montbeliarde, and Scandinavian Red. J. Dairy Sci. 89:2805-2810.

Hollon, B. F., and C. Branton. 1975. Performance of Holstein and crossbred dairy cattle in Louisiana. III. Health and viability. J. Dairy Sci. 58:93-101. 
Jamrozik, J., J. Fatehi, G. J. Kistemaker, and L. R. Schaeffer. 2005. Estimates of genetic parameters for Canadian Holstein female reproduction traits. J. Dairy Sci. 88:2199-2208.

Johanson, J. M., and P. J. Berger. 2003. Birth weight as a predictor of calving ease and perinatal mortality in Holstein cattle. J. Dairy Sci. 86:3745-3755.

Kertz, A. F., L. F. Reutzel, B. A. Barton, and R. L. Ely. 1997. Body weight, body condition score, and wither height of prepartum Holstein cows and birth weight and sex of calves by parity: A database and summary. J. Dairy Sci. 80:525-529.

Lombard, J. E., F. B. Garry, S. M. Tomlinson, and L. P. Garber. 2007. Impacts of dystocia on health and survival of dairy calves. J. Dairy Sci. 90:1751-1760.

Maltecca, C., H. Khatib, V. R. Schutzkus, P. C. Hoffman, and K. A. Weigel. 2006. Changes in conception rate, calving performance, and calf health and survival from the use of crossbred Jersey $x$ Holstein sires as mates for Holstein dams. J. Dairy Sci. 89:27472754 .

McDowell, R. E. 1982. Crossbreeding as a system of mating for dairy production. Southern Coop. Series Bull. No. 259. Louisiana Agric. Exp. Stn., Baton Rouge, LA.

Mee, J. F. 2008. Prevalence and risk factors for dystocia in dairy cattle: A review. Vet. J. 176:93-101.

Meyer, C. L., P. J. Berger, and K. J. Koehler. 2000. Interactions among factors affecting stillbirths in Holstein cattle in the United States. J. Dairy Sci. 83:2657-2663.

Meyer, C. L., P. J. Berger, K. J. Koehler, J. R. Thompson, and C. G. Sattler. 2001. Phenotypic trends in incidence of stillbirth for Holsteins in the United States. J. Dairy Sci. 84:515-523.

Nogalski, Z. 2003. Relations between the course of parturition, body weights and measurements of Holstein-Friesian calves. Czech J. Anim. Sci. 48:51-59.
Norman, H. D., J. R. Wright, M. T. Kuhn, S. M. Hubbard, J. B. Cole, and P. M. VanRaden. 2009. Genetic and environmental factors that affect gestation length in dairy cattle. J. Dairy Sci. 92:2259 2269 .

Olson, K. M., B. G. Cassell, A. J. McAllister, and S. P. Washburn. 2009. Dystocia, stillbirth, gestation length, and birth weight in Holstein, Jersey, and reciprocal crosses from a planned experiment. J. Dairy Sci. 92:6167-6175.

SAS Institute. 2004. SAS/STAT Software, Release 9.1.3. SAS Inst. Inc., Cary, NC.

Silva del Río, N., S. Stewart, P. Rapnicki, Y. M. Chang, and P. M. Fricke. 2007. An observational analysis of twin births, calf sex ratio, and calf mortality in Holstein dairy cattle. J. Dairy Sci. 90:1255-1264.

Touchberry, R. W. 1992. Crossbreeding effects in dairy cattle: The Illinois Experiment, 1949 to 1969. J. Dairy Sci. 75:640-667.

Touchberry, R. W., and B. Bereskin. 1966. Crossbreeding dairy cattle. I. Some effects of crossbreeding on the birth weight and gestation period of dairy cattle. J. Dairy Sci. 49:287-300.

VanRaden, P. M., and Multi-State Project S-1008. 2006. Net merit as a measure of lifetime profit: 2006 revision. http://aipl.arsusda. gov/reference/nmcalc-2006.htm Accessed Dec. 22, 2009

Vesely, J. A., A. J. McAllister, A. J. Lee, T. R. Batra, C. Y. Lin, G. L. Roy, J. M. Wauthy, and K. A. Winter. 1986. Reproductive performance of crossbred and purebred dairy cows. J. Dairy Sci. 69:518-526.

Weigel, K. A., and K. A. Barlass. 2003. Results of a producer survey regarding crossbreeding on US dairy farms. J. Dairy Sci. 86:41484154 .

Zaborski, D., W. Grzesiak, I. Szatkowska, A. Dybus, M. Muszynska, and M. Jedrzejczak. 2008. Factors affecting dystocia in cattle. Reprod. Domest. Anim. 44:540-551. 